\title{
Laparoscopic versus open bowel resection for Crohn's disease
}

\author{
Jeanine Tabet MD PhD ${ }^{1}$, Dennis Hong MD ${ }^{1}$, Cei-Whan Kim MD ${ }^{1}$, Jason Wong BSc MD FRCSC ${ }^{1}$, \\ Robert Goodacre MB BS MRCPUK FRCPSC ${ }^{2}$, Mehran Anvari MB BS PhD FRCSC FACS ${ }^{1}$
}

J Tabet, D Hong, C-W Kim, J Wong, R Goodacre, M Anvari. Laparoscopic versus open bowel resection for Crohn's disease. Can J Gastroenterol 2001;15(4):237-242.

BACKGROUND: Laparoscopic bowel resection is an alternative to open surgery for patients with Crohn's disease requiring surgical resection. The present report describes a seven-year experience with the laparoscopic treatment of Crohn's disease compared with the open technique in a tertiary Canadian centre. PATIENTS AND METHODS: A retrospective analysis of 61 consecutive patients undergoing elective resection for Crohn's disease was carried out between October 1992 and June 1999. This analysis included 32 laparoscopic resections (mean age 33 years) and 29 open resections (mean age 42 years). Patient demographics were compared, as well as short and long term outcomes after surgery (mean follow-up 39 months).

RESULTS: Patients in the laparoscopic group were younger and had fewer previous bowel surgeries than patients who had open resections. Indications for surgery and operative times were similar between the groups. Patients who underwent laparoscopic resections required fewer doses of narcotic analgesics. The resumption of bowel function after surgery, and tolerance of a clear liquid and solid diet was quicker in the laparoscopic group. Patients who underwent laparoscopic resections had significantly shorter hospital stays than those who underwent open resections. Fifteen patients $(48.4 \%)$ in the laparoscopic group experienced recurrence of disease compared with 13 patients $(44.8 \%)$ in the open group. In both groups, the most common site of recurrence was at the anastomosis. The disease-free inter- val was the same length for both groups $(23.9 \pm 17.3$ months for the laparoscopic resection patients compared with $23.9 \pm 20.2$ months for the open resection patients; $\mathrm{P}=1.00$ ).

CONCLUSIONS: Laparoscopic resection for Crohn's disease can be performed safely and effectively. Quicker resumption of oral feeds, less postoperative pain and earlier discharge from hospital are advantages of the laparoscopic method. No differences in the recurrence rate or the disease-free interval were noted.

Key Words: Crohn's disease; Laparoscopy; Surgical outcome

\section{Résection intestinale laparoscopique versus ouverte dans la maladie de Crohn}

HISTORIQUE : La résection intestinale laparoscopique est une solution de rechange à la chirurgie ouverte chez les patients atteints de maladie de Crohn chez qui il faut procéder à une résection chirurgicale. Ce rapport décrit une expérience échelonnée sur sept ans sur le traitement laparoscopique de la maladie de Crohn comparativement à une technique ouverte dans un centre de soins tertiaires canadien.

PATIENTS ET MÉTHODES : Une analyse rétrospective de 61 patients consécutifs devant subir une résection élective pour maladie de Crohn a été effectuée entre octobre 1992 et juin 1999. Cette analyse incluait 32 résections laparoscopiques (âge moyen, 33 ans) et 29 résections ouvertes (âge moyen, 42 ans). Les caractéristiques démographiques des patients ont été comparées, de même que les résultats à court et à long terme de la chirurgie (suivi moyen, 39 mois).

voir page suivante

Departments of ${ }^{1}$ Surgery and ${ }^{2}$ Gastroenterology, St Joseph's Hospital, McMaster University, Hamilton, Ontario

Correspondence and reprints: Dr Mehran Anvari, Department of Surgery, St Joseph's Hospital, 50 Charlton Avenue East,

Hamilton, Ontario L8N 4A6. Telephone 905-522-2952, fax 905-521-6113, e-mail anvari@fhs.mcmaster.ca

Received for publication November 10, 1999. Accepted January 18, 2000 
RÉSULTATS : Les patients du groupe sous laparoscopie étaient plus jeunes et avaient été opérés moins souvent à l'intestin que les patients qui avaient subi une résection ouverte. Les indications de la chirurgie et la durée des interventions ont été semblables dans les deux groupes. Les patients qui ont subi des résections laparoscopiques ont eu besoin de doses moins nombreuses d'analgésiques de type narcotique. La reprise de la fonction intestinale après la chirurgie et la tolérance d'une alimentation à base de liquide clair et de solides ont été plus rapides dans le groupe ayant subi la laparoscopie. Les patients de ce groupe ont en outre séjourné significativement moins longtemps à l'hôpital que les patients qui ont subi une chirurgie ouverte. Quinze patients $(48,4 \%) \mathrm{du}$ groupe laparoscopie ont connu une récurrence de la maladie, contre 13
(44,8 \%) dans le groupe sous intervention ouverte. Dans les deux groupes, le site le plus fréquent des récurrences a été l'anastomose. L'intervalle sans maladie a été de la même durée pour les deux groupes $(23,9 \pm 17,3$ mois pour les patients ayant subi la résection laparoscopique, contre 23,9 $\pm 20,2$ mois pour les patients ayant subi la résection ouverte, $\mathrm{p}=1,00$ ).

CONCLUSIONS : La résection laparoscopique pour la maladie de Crohn peut être effectuée de façon sécuritaire et efficace. La reprise plus rapide de l'alimentation orale, la douleur post-opératoire moins grande et le congé plus hâtif de l'hôpital sont des avantages associés à la méthode laparoscopique. On n'a noté aucune différence quant au taux de récurrence ou quant à l'intervalle sans maladie.
$\mathrm{O}$ ver the past decade, a number of laparoscopic procedures, including laparoscopic bowel resections, have gained wide acceptance. While the use of laparoscopic surgery for the treatment of colorectal cancer is still controversial, many authors have reported good results when laparoscopic techniques are used in patients with benign colorectal disease, especially in those with Crohn's disease (1-9); a shorter hospitalization is of benefit to this population of mainly young and employed people.

Despite the reported short term benefits of the laparoscopic technique, most Canadian centres do not offer this alternative to patients with Crohn's disease requiring surgery. This is, in part, due to a lack of adequate long term follow-up to examine the disease-free interval and the long term outcome after laparoscopic surgery. There is also a lack of surgeons with the necessary skills to offer these procedures. Until convincing evidence is accumulated to show the clear benefits of this technique, the current status is unlikely to change significantly.

This short and long term outcomes of 61 patients undergoing elective resection for Crohn's disease by open and laparoscopic techniques in a tertiary centre in Canada are reported.

\section{PATIENTS AND METHODS}

Patients: Sixty-one consecutive patients who underwent elective surgery for Crohn's disease between October 1992 and June 1999 were studied. They were assessed preoperatively by physical examination, contrast radiography, ultrasonography, computed tomography scan (where applicable) and endoscopy. All patients underwent a standard mechanical bowel preparation and received preoperative broad spectrum antibiotics. Patients who underwent surgery for the recurrence of Crohn's disease were included. Converted cases were included in the laparoscopic group.

Surgical technique: All patients underwent either laparoscopic-assisted resections by two surgeons experienced in minimally invasive surgery or open resections by nine surgeons at the authors' institution. Operative techniques for laparoscopic resections have been described elsewhere $(10,11)$. Bowel mobilization was done laparoscopically through four or five trocars. Bowel resection and anastomosis were performed extracorporeally through a small (4 to $6 \mathrm{~cm}$ ) muscle splitting incision, except for anterior resections, in which anastomosis was done intracorporeally. A stapled anastomosis was performed in all cases. Conversion to the open technique was indicated when the surgeon was unable to fully mobilize the diseased segment laparoscopically and a larger incision was necessary to complete the resection.

Postoperative care: Oral intake was initiated by the first postoperative day. Postoperative pain was objectively assessed by evaluation of the total number of days that parenteral and oral narcotic analgesics were needed. Length of hospitalization was defined as the length of postoperative stay. Complications were classified as major (life-threatening) or minor (nonlife-threatening). Perioperative mortality was defined as death occurring within 30 days after the operation.

Outcome variables measured: Parameters reviewed included patient characteristics, operative variables, and short term and long term outcomes. Patient characteristics included age, sex, smoking habit, previous surgery, indications for surgery and time from diagnosis of the disease to first surgery. Operative variables included type of resection, operative time, conversion to open surgery and intraoperative complications. Short term outcomes included postoperative complications, time to resumption of oral intake, time to first bowel movement, number of days on analgesics, length of stay and 30-day mortality. Long term outcomes included recurrence rate, disease-free interval and number of re-operations. Recurrence of disease was defined as the recurrence of preoperative symptoms with confirmation by contrast radiography and/or endoscopy with biopsy.

Statistical analysis: Continuous variables were compared using Student's two-tailed $t$ test. Categorical variables were analyzed using Pearson's $\chi^{2}$ test or Fisher's exact test. Results are reported as means ( \pm SD). Significance was considered at $\mathrm{P}<0.05$.

\section{RESULTS}

Patient demographics and indications for surgery: From a total of 61 patients, 32 underwent laparoscopic-assisted resections and 29 underwent open resections on an elective basis (Table 1). Patients in the laparoscopic group were younger $(33 \pm 15$ years $)$ than those in the open group $(42 \pm 19$ years $)(P=0.04)$. Fifteen patients in the open group 
TABLE 1

Comparison of patient demographics for 61 patients undergoing laparoscopic $(n=32)$ and open $(n=29)$ bowel resection

\begin{tabular}{|c|c|c|c|}
\hline & $\begin{array}{c}\text { Laparoscopic } \\
\text { bowel } \\
\text { resection }\end{array}$ & $\begin{array}{c}\text { Open } \\
\text { bowel } \\
\text { resection }\end{array}$ & Difference \\
\hline Number & 32 & 29 & \\
\hline Age (years) & $33 \pm 15$ & $42 \pm 19$ & $P=0.04$ \\
\hline Sex ratio (male:female) & $14: 18$ & $8: 21$ & NS \\
\hline Smoking habit & 10 & 8 & NS \\
\hline Steroid use & 28 & 21 & NS \\
\hline Previous bowel surgery & 3 & 15 & $\mathrm{P}<0.001$ \\
\hline $\begin{array}{l}\text { Time from diagnosis } \\
\text { to first surgery (years) }\end{array}$ & $6.3 \pm 6.5$ & $4.4 \pm 7.2$ & NS \\
\hline ASA score & & & NS \\
\hline 1 & 2 & 2 & \\
\hline 2 & 27 & 21 & \\
\hline 3 & 3 & 6 & \\
\hline
\end{tabular}

ASA American Society of Anesthesiology; NS Not significant

TABLE 2

Indications for surgery in $\mathbf{6 1}$ patients undergoing laparoscopic $(n=32)$ and open $(n=29)$ bowel resection

\begin{tabular}{lccc}
\hline & $\begin{array}{c}\text { Laparoscopic bowel } \\
\text { resection (\%) }\end{array}$ & $\begin{array}{c}\text { Open bowel } \\
\text { resection (\%) }\end{array}$ & Difference \\
\hline Inflammation & $17(53.1)$ & $10(37)$ & NS \\
Stricture & $3(9.4)$ & $5(17.2)$ & NS \\
Abscess & $2(6.3)$ & $6(20.7)$ & NS \\
Fistula & $10(31.3)$ & $8(27.6)$ & NS
\end{tabular}

NS Not significant

had undergone previous bowel surgery, while only three patients in the laparoscopic group had experienced a previous resection $(\mathrm{P}<0.001)$. The indications for surgery (Table 2) were similar between the two groups.

Operative outcomes: Ileocolonic resections were performed more frequently in the laparoscopic group, while left colonic resections and resections of the anastomotic site were completed more frequently in the open group (Table 3 ).

In four of the 32 laparoscopic patients, the surgery was converted to an open resection $(12.5 \%)$; these conversions were all due to the presence of a large inflammatory mass with adherence to surrounding structures.

There was no difference in operative times between the two groups (laparoscopic 124.1 $\pm 53.4 \mathrm{~min}$, open $122.9 \pm 36.6$ min; $\mathrm{P}=0.92$ ). No intraoperative complications were recorded in either group.
TABLE 3

Type of resections performed in 61 patients after laparoscopic $(n=32)$ and open $(n=29)$ bowel resection

\begin{tabular}{lcc}
\hline Type of resection & $\begin{array}{c}\text { Laparoscopic bowel } \\
\text { resection (\%) }\end{array}$ & $\begin{array}{c}\text { Open bowel } \\
\text { resection (\%) }\end{array}$ \\
\hline Ileocolonic & $24(75)$ & $15(51.7)$ \\
Left hemicolectomy & $4(12.5)$ & $4(13.8)$ \\
Abdominoperineal & $1(3.1)$ & $1(3.4)$ \\
Right and sigmoid & 0 & $1(3.4)$ \\
Total colectomy & 0 & $1(3.4)$ \\
Hartmann's procedure & $1(3.1)$ & $2(6.9)$ \\
Transverse colectomy & & 0 \\
$\quad$ and colostomy & $1(3.1)$ & $5(17.2)$ \\
Anastomotic site resection & $1(3.1)$ & \\
\hline
\end{tabular}

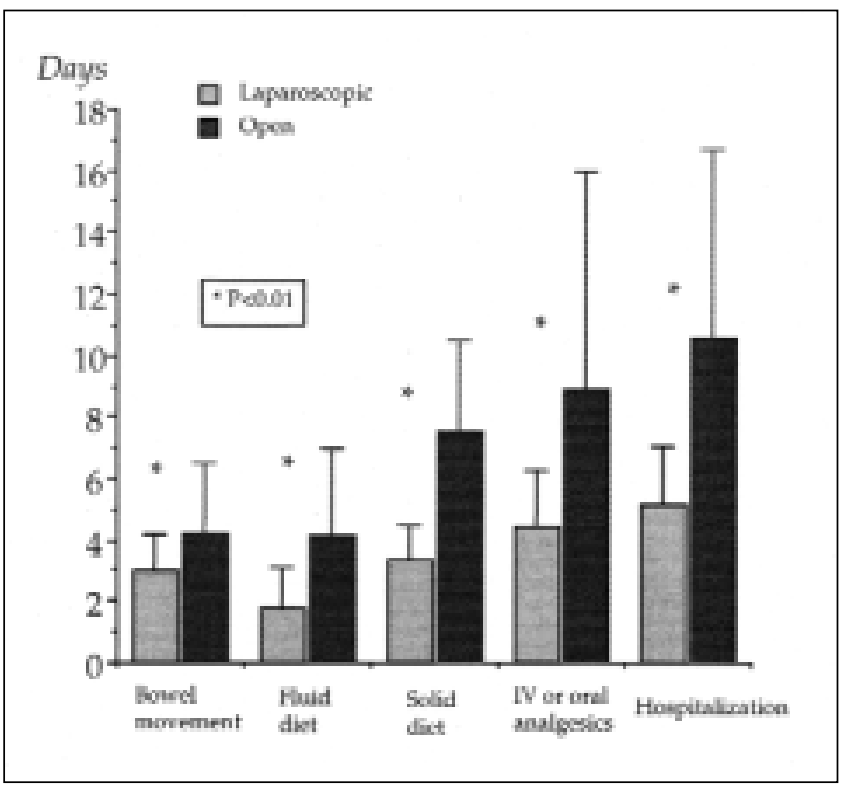

Figure 1) The short term outcome and length of hospital stay in 61 patients after laparoscopic $(n=32)$ and open $(n=29)$ bowel resection. IV Intravenous

Postoperative recovery and complications: Patients in the laparoscopic group required fewer doses of narcotic analgesics and a shorter hospitalization (Figure 1). These patients tolerated a clear fluid diet and solid diet earlier than the open group. The time to first bowel movement was also significantly earlier. No perioperative mortality was reported in either group. There was no statistical difference in the rate of major complications between the two groups; however, minor complications were significantly more frequent in the open group (Table 4). Two patients in the open group had a prolonged postoperative ileus (longer than three days).

Comparison of patients with no previous surgery: There were 29 patients in the laparoscopic group and 14 patients in the open group who had no previous abdominal surgery. The two groups were comparable with respect to age, dura- 
TABLE 4

Postoperative complications in 61 patients after laparoscopic $(n=32)$ and open $(n=29)$ bowel resection

\begin{tabular}{lccl}
\hline & $\begin{array}{c}\text { Laparoscopic } \\
\text { bowel } \\
\text { resection } \\
\mathbf{n = 3 2} \text { (\%) }\end{array}$ & $\begin{array}{c}\text { Open } \\
\text { bowel } \\
\text { resection } \\
\mathbf{n = 2 9}(\%)\end{array} \quad$ Difference \\
\hline Major complications & $1(3.1)$ & 0 & \\
$\quad$ Colostomy revision & 0 & $1(3.4)$ & \\
Sepsis & 0 & $3(4.9)$ & \\
Intra-abdominal abscess & 0 & $1(3.4)$ & \\
Enterocutaneous fistula & $1(3.1)$ & $5(17.2)$ & $\mathrm{P}=0.06$ \\
Total & & & \\
Minor complications & $2(6.3)$ & 0 & \\
$\quad$ Readmission for pain & 0 & $1(3.4)$ & \\
Urinary infection & 0 & $2(6.9)$ & \\
Ileus & $1(3.1)$ & $2(6.9)$ & \\
Wound infection & 0 & $1(3.4)$ & \\
Atelectasis & 0 & $1(3.4)$ & \\
Deep vein thrombosis & $3(9.4)$ & $7(24.1)$ & $\mathrm{P}<0.05$ \\
\hline Total & & &
\end{tabular}

TABLE 5

Comparison of subgroup of 43 patients with no previous surgery for Crohn's disease (29 laparoscopic and 14 open bowel resection patients)

\begin{tabular}{lccc}
\hline & $\begin{array}{c}\text { Laparoscopic } \\
\text { bowel } \\
\text { resection }\end{array}$ & $\begin{array}{c}\text { Open } \\
\text { bowel } \\
\text { resection }\end{array}$ & Difference \\
\hline Number & 29 & 14 & \\
Age (years) & $33 \pm 14$ & $40 \pm 17$ & NS \\
Sex ratio (male:female) & $11: 18$ & $3: 11$ & NS \\
Steroid use & 26 & 10 & NS \\
Time from diagnosis & $5.9 \pm 5.7$ & $4.9 \pm 10.2$ & NS \\
$\quad$ to first surgery (years) & & 10 & NS \\
lleocecal resection & 21 & $128 \pm 35$ & $\mathrm{NS}$ \\
Operative time (min) & $125 \pm 55$ & & \\
Postoperative complications & & $3(21.4 \%)$ & $\mathrm{P}=0.05$ \\
$\quad$ Major & $1(3.4 \%)$ & $4(28.6 \%)$ & $\mathrm{NS}$ \\
\hline Minor & $4(13.8 \%)$ & & \\
\hline
\end{tabular}

NS Not significant

tion of symptoms and use of steroids before surgery. The mean operating time was similar between groups (Table 5). The laparoscopic patients experienced an earlier return of bowel activity and a shorter hospital stay, and required fewer doses of narcotic analgesics (Figure 2). No statistical difference in complication rates was found between the groups (Table 5).

Recurrence of disease: The recurrence rate of Crohn's disease was similar in both groups $(46.9 \%$ in the laparoscopic

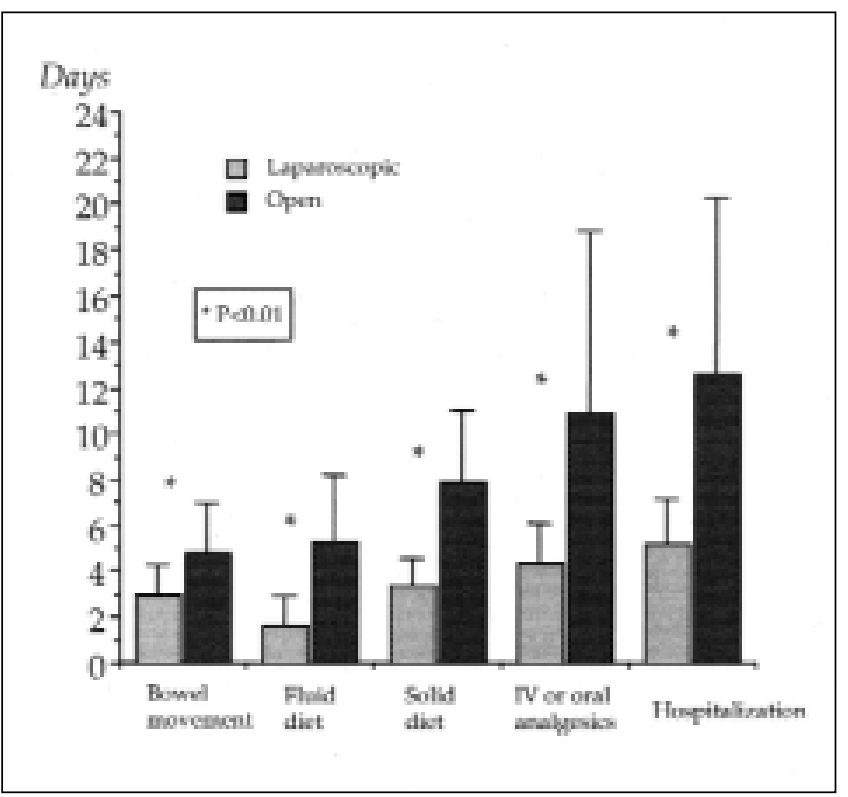

Figure 2) Postoperative recovery and length of hospital stay in a subgroup of 43 patients with no previous bowel surgery (29 laparoscopic and 14 open bowel resection patients). IV Intravenous

\section{TABLE 6}

Recurrence rates of Crohn's disease according to recurrence site for 61 patients after laparoscopic $(n=32)$ and open $(n=29)$ bowel resection

\begin{tabular}{lccc}
\hline $\begin{array}{l}\text { Recurrence } \\
\text { site }\end{array}$ & $\begin{array}{c}\text { Laparoscopic bowel } \\
\text { resection (\%) }\end{array}$ & $\begin{array}{c}\text { Open bowel } \\
\text { resection (\%) }\end{array}$ & Difference \\
\hline Anastomosis & $10(31.3)$ & $7(24.1)$ & \\
Colon & $3(9.4)$ & $4(13.9)$ & \\
Perineum & $1(3.1)$ & 0 & \\
Small bowel & $1(3.1)$ & $2(6.9)$ & \\
Total & $15(46.9)$ & $13(44.8)$ & 0.6 \\
\hline
\end{tabular}

group compared with $44.8 \%$ in the open group; $\mathrm{P}=0.87$ ), with a mean follow-up of 38.7 months in the laparoscopic group and 41.7 months in the open group. The most common site of recurrence was at the anastomosis (Table 6). More patients in the open group (10 patients) needed reoperations due to the recurrence of Crohn's disease than in the laparoscopic group (four patients) $(\mathrm{P}=0.01)$. The disease-free interval was similar between groups $(23.9 \pm 17.3$ months in the laparoscopic group compared with $23.9 \pm 20.2$ months in the open group; $\mathrm{P}=1.00$ ).

When examining the subgroup of 43 patients without previous bowel surgery, there were no differences in recurrence rate or the site of recurrence between the two groups.

\section{DISCUSSION}

The present study is a comparative study of laparoscopic versus open resection for Crohn's disease. It demonstrates that laparoscopic surgery can be performed safely and has 
clear short term benefits over traditional open resection for Crohn's disease. This is not a randomized trial and, therefore, has the limitations of a nonrandomized cohort study. There were differences between the two groups that may have had an impact on the observed outcomes. The open patient group was, on average, older and contained more patients who had previous abdominal surgery, suggesting a possible selection bias. However, analysis of a comparable subgroup of 43 patients (29 laparoscopic patients and 14 open patients) with no previous bowel surgery showed similar results with regard to the superiority of the laparoscopic approach in the short term after surgery.

We believe that the larger number of younger patients in the laparoscopic group reflects patient demand and preference for minimally invasive surgery in this age group. This is supported by observations of Dunker et al (12), who evaluated cosmetic scores between Crohn's patients who underwent either laparoscopic or open resection. They found that patients who underwent laparoscopic resection had significantly better cosmetic scores than those who underwent open resection. Furthermore, they found that the majority of patients preferred laparoscopic surgery, even if it would entail a higher risk of reoperation or higher fees. Thus, the improved cosmetic results after laparoscopic surgery play a significant role in the popularity of this new technique, particularly among younger patients. Moreover, when the first operation is performed laparoscopically, it allows for easier reoperation, if necessary, because of a lack of significant adhesions that sometimes complicate open resections.

Some authors have expressed concerns that complicated Crohn's disease may be a contraindication to the use of the laparoscopic technique $(6,7)$. However, this sentiment is changing. Wu et al (1) showed that laparoscopic ileocolic resection can be performed safely in patients with complicated Crohn's disease. In our experience, 12 complicated cases have been managed successfully laparoscopically. None of the conversions in our study occurred in patients with abscess or fistula.

We have shown that patients who undergo laparoscopic resections resume an oral diet more quickly, experience less pain and, most importantly, have a shorter hospital stay. These benefits are comparable with those reported in other studies of laparoscopic-assisted resection for Crohn's disease $(1,3,4)$. The length of hospitalization after bowel surgery is mainly dependent on the resolution of postoperative ileus, resumption of an oral diet and control of postoperative pain. Objective data from animal studies have shown that gastrointestinal transit time is shorter after laparoscopic resection as than after open resection (13). This has important economic consequences; savings from a shorter hospitalization offsets the increased operating room costs of laparoscopic surgery. An economic analysis in the setting of a randomized trial would be helpful to determine all of the potential benefits of laparoscopic resection for Crohn's disease.

We also found no differences in the disease-free interval or the sites of recurrence between the two techniques. In fact, the median disease-free interval was greater in the laparoscopic group. This may be due to a patient selection bias or differences in disease severity. Yet, data from animal studies have shown that immune function is better preserved after laparoscopic colon resection (14). Further evaluation is needed to determine whether this observation is true in Crohn's patients and how this impacts on recurrence of disease.

Our experience indicates that there are no absolute contraindications for laparoscopic resection compared with the open approach. There are, however, a number of factors that may make conversion more likely. These include surgeon experience, the number and extent of previous abdominal surgeries, the presence of extensive internal fistula and the involvement of retroperitoneal structures. Even if conversion becomes necessary, the initial laparoscopic approach may allow the surgeon to carry out some of the dissection laparoscopically and reduce the size of incision necessary to complete the resection. Therefore, we suggest that the laparoscopic approach should be the first method of access into the peritoneal cavity for all patients with Crohn's disease requiring surgery and that patients should be appropriately informed of the possibility of conversion.

\section{CONCLUSIONS}

Laparoscopic bowel surgery can be performed safely and effectively in patients with Crohn's disease. Compared with open surgery, patients undergoing laparoscopic resections experience less pain, resume oral diet and bowel function earlier, and have a shorter hospital stay. There seems to be no deleterious effects on the long term course of the disease from the use of the laparoscopic approach. Prospective randomized trials may be needed, however, before the laparoscopic approach can be considered the 'gold' standard in the surgical care of Crohn's patients.

ACKNOWLEDGEMENTS: The authors thank Catherine Gill for her help with the database and Jose Belda MD for his assistance in statistical analysis.

\section{REFERENCES}

1. Wu JS, Birnbaum EH, Kodner IJ, Fry RD, Read TE, Fleshman JW. Laparoscopic-assisted ileocolic resections in patients with Crohn's disease: Are abscess, phlegmons, or recurrent disease contraindications? Surgery 1997;122:682-9.

2. Canin-Endres J, Salky B, Gattorno F, Edye M. Laparoscopically assisted intestinal resection in 88 patients with Crohn's disease. Surg Endosc 1999;13:595-9.

3. Reissman P, Salky BA, Edye M, Wexner SD. Laparoscopic surgery in Crohn's disease. Indications and results. Surg Endosc 1996;10:1201-3.

4. Bauer JJ, Harris MT, Grumbach NM, Gorfine SR. Laparoscopicassisted intestinal resection for Crohn's disease. Which patients are good candidates? J Clin Gastroenterol 1996;23:44-6.

5. Jess P, Moller EH, Ladefoged K, Christiansen J. Laparoscopic-assisted ileocecal resection for Crohn's disease: a preliminary study. Scand J Gastroenterol 1996;31:302-4.

6. Ludwig KA, Milsom JW, Church JM, Fazio VW. Preliminary experience with laparoscopic intestinal surgery for Crohn's disease. Am J Surg 1996;171:52-5. 


\section{Tabet et al}

7. Bauer JJ, Harris MT, Grumbach NM, Gorfine SR. Laparoscopicassisted intestinal resection for Crohn's disease. Dis Colon Rectum 1995:38:712-5.

8. Milsom JW, Lavery IC, Bohm B, Fazio VW. Laparoscopically assisted ileocolectomy in Crohn's disease. Surg Laparosc Endosc 1993;3:77-80.

9. Thibault C, Poulin EC. Total laparoscopic proctocolectomy and laparoscopy-assisted proctocolectomy for inflammatory bowel disease: operative technique and preliminary report. Surg Laparosc Endosc 1995;5:472-6.

10. Elftmann TD, Nelson H, Ota DM, Pemberton JH, Beart RW Jr. Laparoscopic-assisted segmental colectomy. Mayo Clin Proc 1994;69:825-33.
11. Jacobs M, Verdeja JC, Goldstein HS. Minimally invasive colon resection (laparoscopic colectomy). Surg Laparosc Endosc 1991;1:144-50.

12. Dunker MS, Stiggelbout AM, van Hogezand RA, Ringers J, Griffioen G, Bemelman WA. Cosmesis and body image after laparoscopic-assisted and open ileocolic resection for Crohn's disease. Surg Endosc 1998;12:1334-40.

13. Davies W, Kollmorgen CF, Tu QM, et al. Laparoscopic colectomy shortens postoperative ileus in a canine model. Surgery 1997;121:550-5.

14. Bessler M, Whelan RL, Halverson A, Treat MR, Nowygrod R. Is immune function better preserved after laparoscopic versus open colon resection? Surg Endosc 1994;8:881-3. 


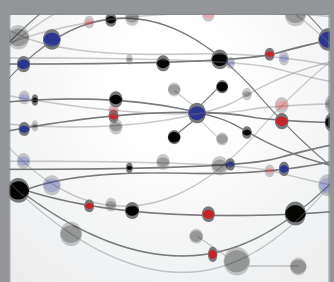

The Scientific World Journal
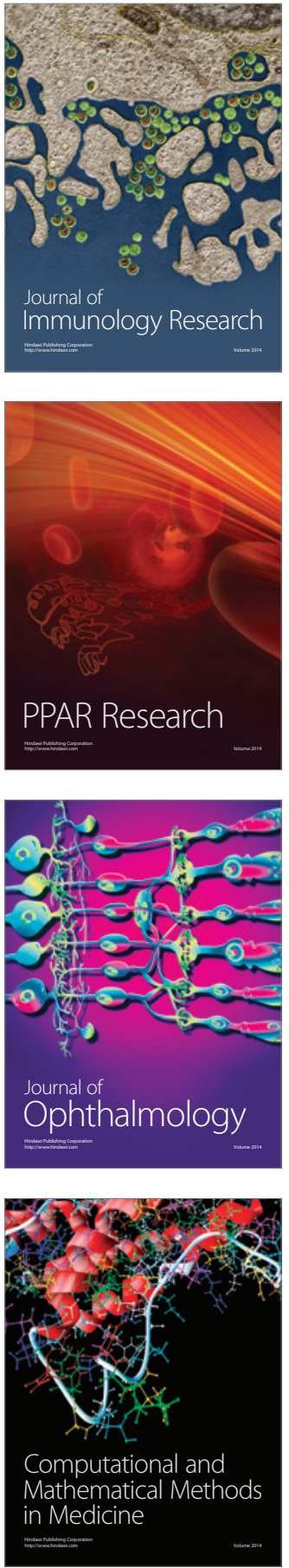

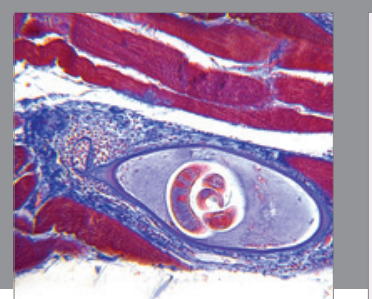

Gastroenterology Research and Practice

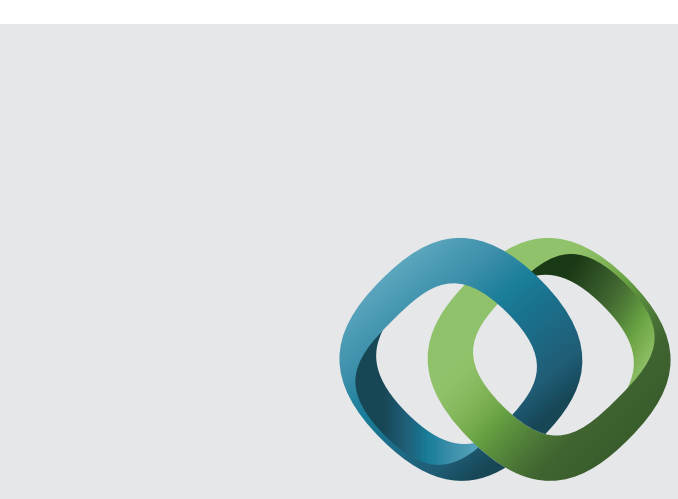

\section{Hindawi}

Submit your manuscripts at

http://www.hindawi.com
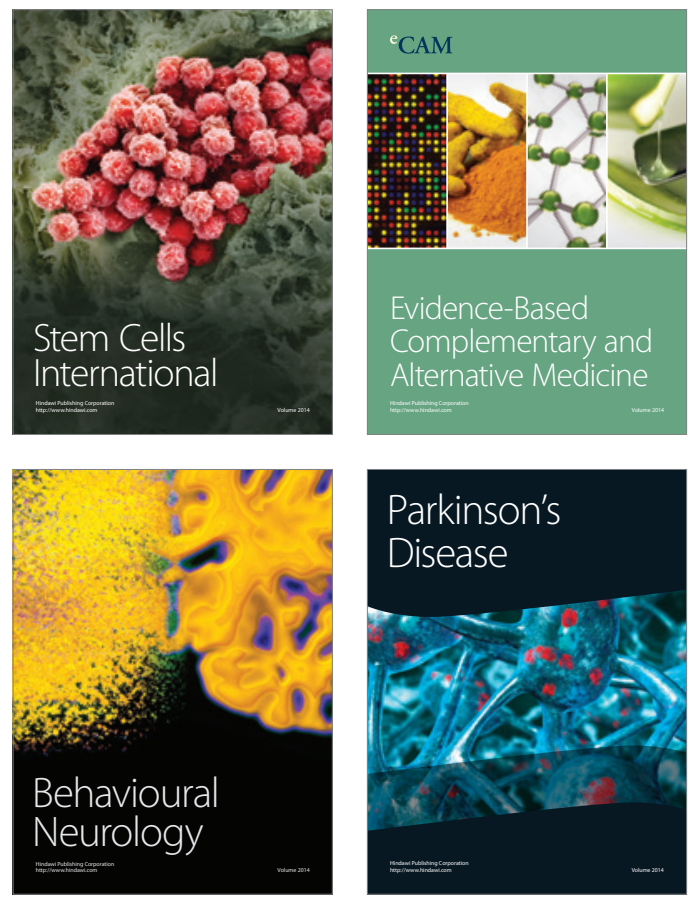
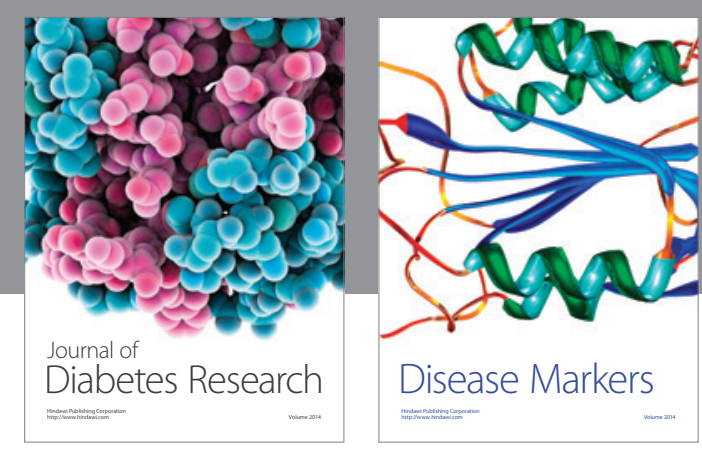

Disease Markers
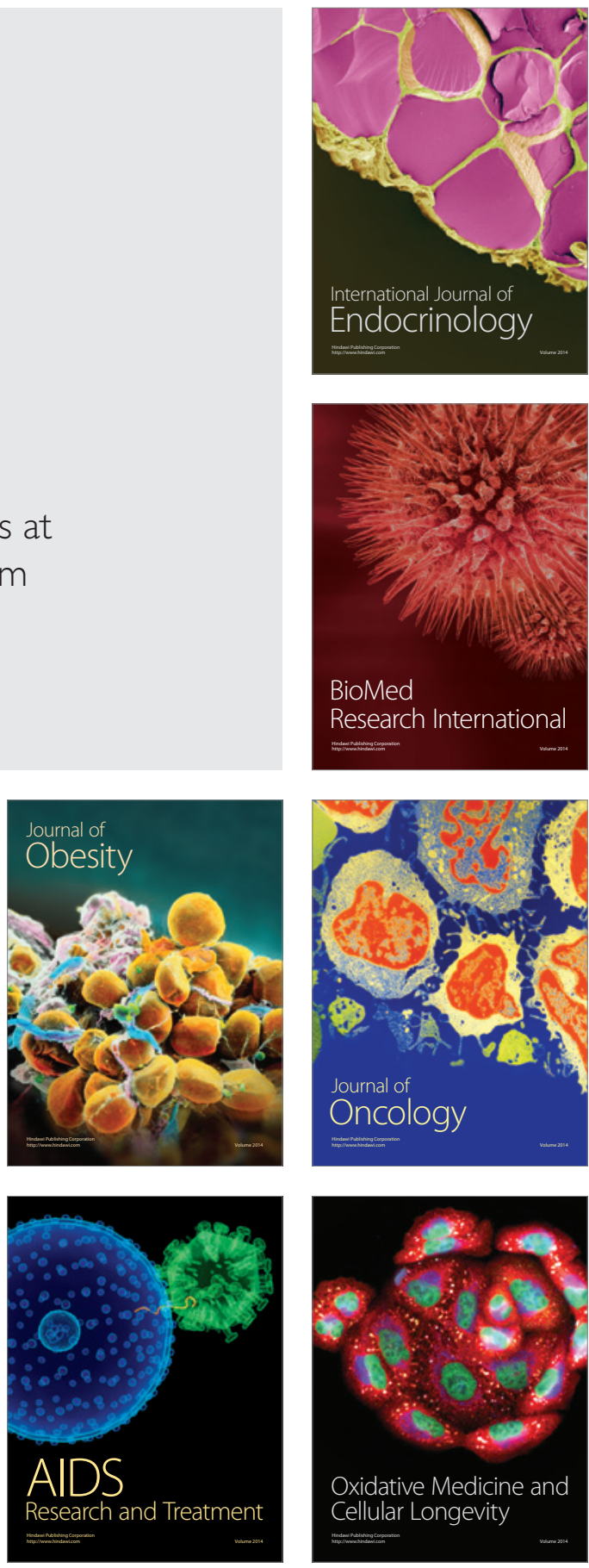